\title{
RESEARCH OF THE SEASON MINERALS OF MUD VULCANOES IN KERCH PENINSULA V.A. Nesterovskiy', M.A. Deyak²
}

\section{ДОСЛІДЖЕННЯ СЕЗОННИХ МІНЕРАЛІВ ГРЯЗЬОВИХ ВУЛКАНІВ КЕРЧЕНСЬКОГО ПІВОСТРОВА}

\author{
В.А. Нестеровський ${ }^{1}$, М.А. Деяк ${ }^{2}$
}

New data about season minerals from Bulganyak, Tarchan, Burulkay and Konchek mud volcanoes in Kerch Peninsula are proposed. Their disaggregation forms, optic feature and formation conditions from the water phase are described.

Key words: mud volcanoes, season minerals, genesis.

Наведено нові дані про сезонні мінерали Булганакського, Тарханського, Бурулькайського та Кончекського грязьових вулканів Керченського півострова. Розглянуто їх форми виділення, оптичні властивості та умови утворення з водної фази.

Ключові слова: грязьовий вулкан, сезонні мінерали, генезис.

\section{ВСТУП}

Грязьові вулкани є специфічними природними об'єктами, в яких відбувається гідротермальне і екзогенне мінералоутворення. Серед мінералів гідротермального походження в грязьових вулканах Керченського півострова попередніми дослідженнями встановлено такі мінерали, як графіт, ауріпігмент, вюрцит, галеніт, дюфренуазит, кіновар, пірит, халькопірит, марказит, молібденіт, реальгар, сфалерит, родохрозит, сидерит, флюорит, піролюзит, кальцит, барит, апатит. 3 аутигенних мінералів екзогенного походження в грязьових джерелах описанно: сульфати (гіпс, ангідрит, епсоміт, астраханіт, гексагідрит, галотрихіт), борати (бура, люнебургит, боронатрокальцит, тинкалконіт, керніт), а також галіт [1-4]. Останнім часом цей список суттєво поповнено. Вода, що виділяється з грязьових вулканів на поверхню, особливо в літній період, за рахунок інтенсивного випаровування стає перенасиченою і сприятливою для мінералоутворення. Тут відбувається кристалізація, головним чином водорозчинних сезонних мінералів. Залежно від гідрохімічного складу сопкових вод, набір мінеральних новоутворень для різних грязьових вулканів може відрізнятись і навіть суттєво. Це підтвердили і наші дослідження.

\section{РАЙОН РОБІТ, МЕТОДИ ТА ОБ'ЄКТИ ДОСЛІДЖЕННЯ}

Для дослідження обрано Булганакський, Тарханський, Бурулькайський та Кончекський грязьові вулкани, що знаходяться в різних структурах Керченського півострова - Позапарпачській області та Південно-Західній рівнині. Всі грязьові вулкани ускладнені вдавленими синкліналями, мають різну глибину залягання кореневої системи. Нині ці вулкани знаходяться в пасивній, газо-грифонній стадії розвитку, виділяють на поверхню сопкову воду та газ. Булганакський і Тарханський грязьові вулкани, крім цього, викидають і сопкову грязь. Сопкова вода з грязьових вулканів витікає тонкими струмками у напрямку зниження рельєфу, залишаючи на поверхні ґрунту після висихання білі виділення. Це кірки, нальоти, пухкі снігоподібні маси, жовна. Товщина виділень від декількох міліметрів до 10 мм.

Нами досліджувалися сопкова вода і мінеральні новоутворення. Для цього використовувались хімічний, мікроскопічний та рентгеноструктурний методи дослідження. Крім цього проведено експеримент з розчинення та кристалізації полімінеральних агрегатів для встановлення послідовності кристалоутворення.

\section{РЕЗУЛЬТАТИ ДОСЛІДЖЕННЯ ТА ЇХ АНАЛІЗ}

Нашими дослідженнями у відкладах сопкових вод згаданих грязьових вулканів встановлено мінерали класу боратів, карбонатів, сульфатів, нітратів і хлоридів.

Борати. Встановлені на Булганакському та Тарханському грязьових вулканах. Вони представлені двома мінералами - бурою та тинкалконітом. 


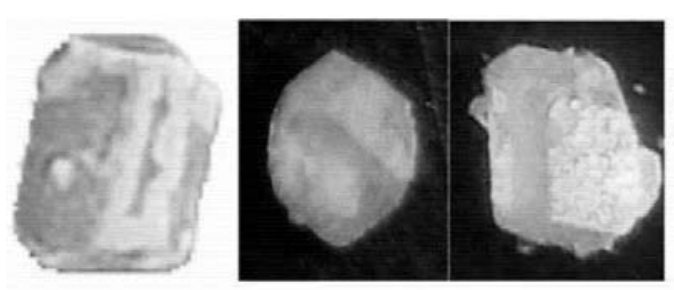

Рис. 1. Морфологія кристалів бури

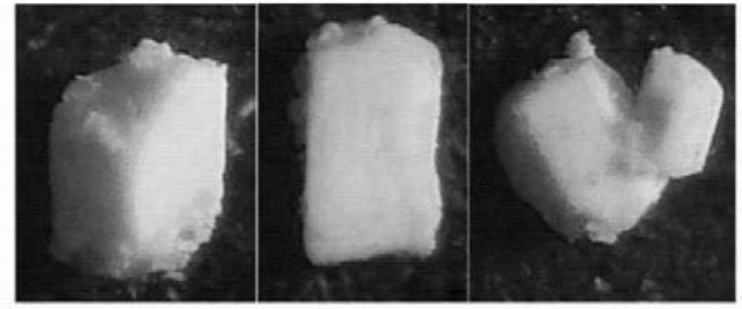

Рис. 2. Псевдоморфози тинкалконіту по бурі

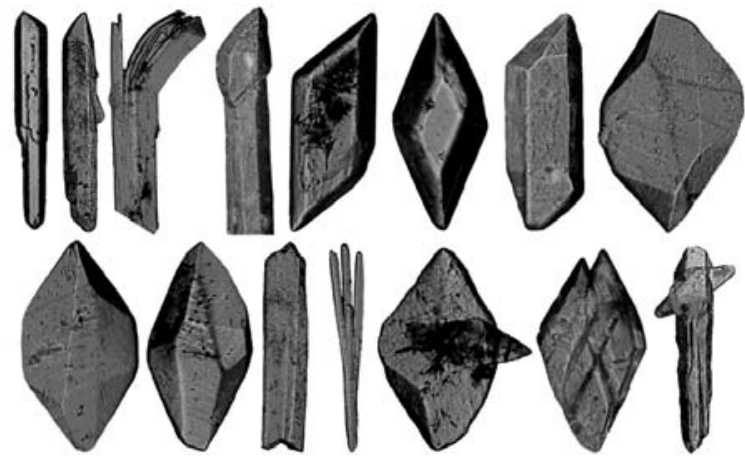

Рис. 3. Морфологія кристалів гіпсу (Кончек)
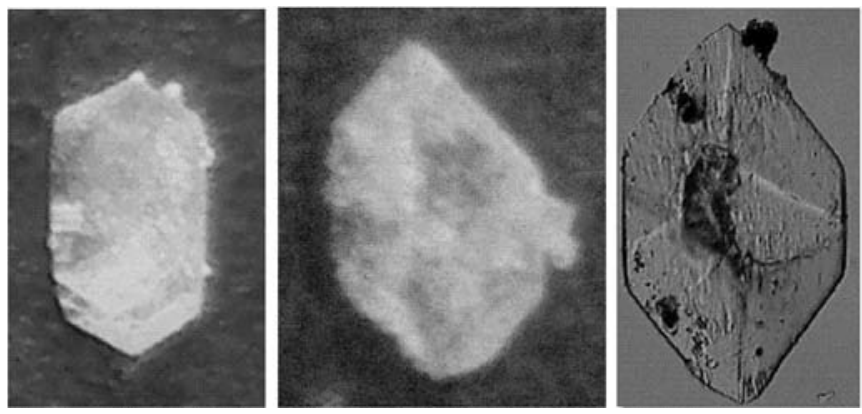

Рис.4. Морфологія кристалів гіпсу (Бурулькая)

Бура - $\mathrm{Na}_{2} \mathrm{~B}_{4} \mathrm{O}_{5}(\mathrm{OH})_{4} \times 8 \mathrm{H}_{2} \mathrm{O}$. Встановлена лише на Булганакському грязьовому вулкані у вигляді індивідуальних кристалів та цукроподібної тонкозернистої маси. Кристали бури безбарвні, прозорі, зі скляним блиском, добре ограновані. Їх габітус призматичний, призматично-дипірамідальний (рис.1). Обрис кристалів стовбчастий, ізометричний. Розмір індивідів 0,1-0,7мм. Кристали оптично двовісні (-), Ng'-1,470. На рентгенограмі бури з Булганакського грязьового вулкану виявляються чіткі рефлекси 5.719(19), 5.205(6), 4.865(19), 3.948(11), 3.009(32), 2.825(80), 2.597(30), 2.564(30), 2.333(17). На деяких кристалах добре помітні сліди розчинення.

Тинкалконіт - $\mathrm{Na}_{2} \mathrm{~B}_{4} \mathrm{O}_{7} \times 5 \mathrm{H}_{2} \mathrm{O}$. Встановлений разом з бурою в природних полімінеральних утвореннях Булганакського та Тарханського грязьових вулканів. Його рефлекси на рентгенограмах відповідають значенням - 8.820(33), 5.590(23), 4.716(34), 4.397(93), 3.453(57), 3.009(32), 2.930(100), 2.768(28), 2.597(30), 2.264(34), 2.190(42), 1.997(42), 1.797(29). Візуально цей мінерал спостерігається лише у вигляді псевдоморфоз по бурі (рис.2). Визначити його кристалооптичні параметри у природному стані і отримати кристали після розчинення природних полімінеральних утворень нам не вдалось.

Карбонати. Трона - $\mathrm{Na}_{3} \mathrm{H}\left(\mathrm{CO}_{3}\right)_{2} \times 2 \mathrm{H}_{2} \mathrm{O}$. Встановлена у складі полімінеральних агрегатів у відкладах сопкових вод Булганакського та Тарханського грязьових вулканів. Ї̈̈ рефлекси на рентгенограмі 9.839(13), 4.908(14), 3.202(17), 3.081(38), 2.650(52), 2.447(20), 2.257(22), 2.043(13), 2.030(17). Кристали трони відсутні. Отримати їх синтетичним шляхом після розчинення полімінеральних агрегатів нам також не вдалось.

Сульфати. Цей клас представлений найбільш чисельною групою мінералів.

Гіпс - $\mathrm{CaSO}_{4} \times 2 \mathrm{H}_{2} \mathrm{O}$. Встановлений серед новоутворених мінералів Бурулькайського та Кончекського грязьових вулканів у вигляді індивідуальних кристалів та закономірних зростків. Габітус кристалів: Кончек - призматичний, пінакоїдальний, призматично-біпірамідальний; Бурулькая - призма-
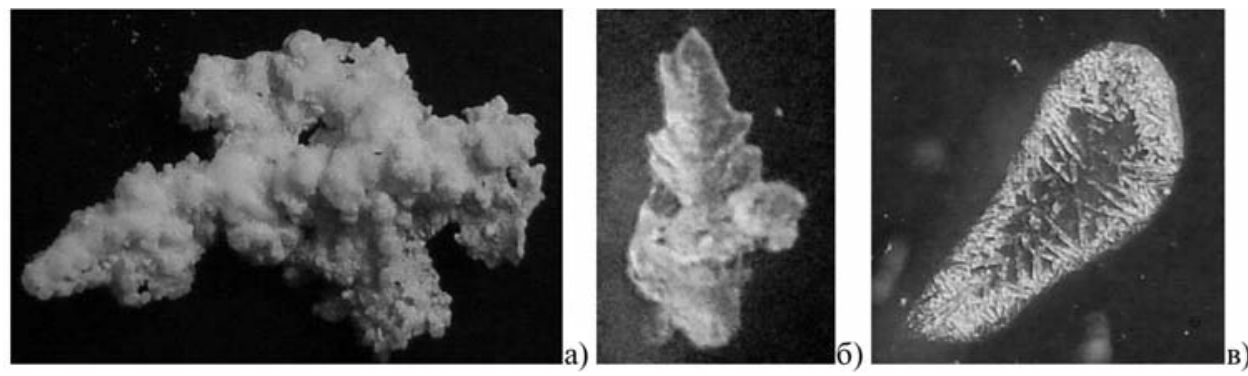

Рис.5. Морфологія природних (а) та експериментально отриманих (б, в) агрегатів тенардиту 

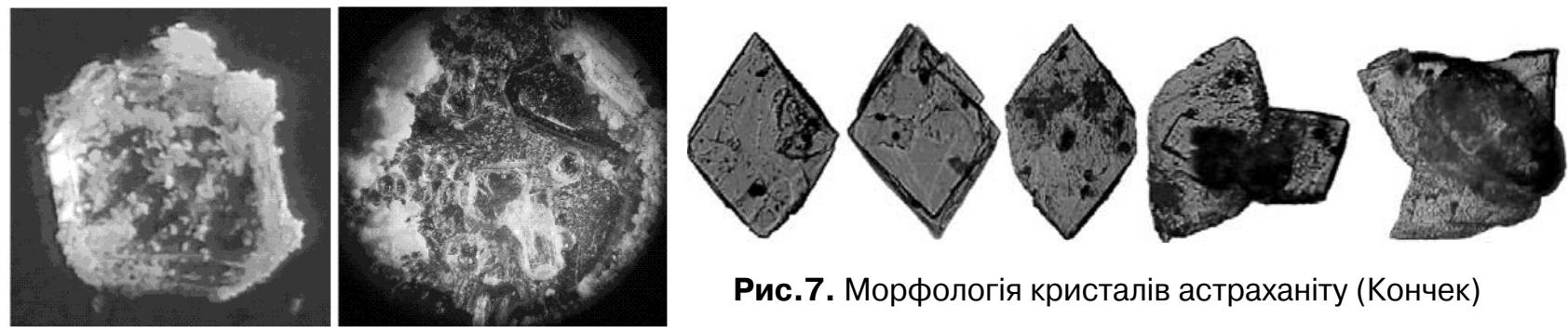

Рис.7. Морфологія кристалів астраханіту (Кончек)

Рис.6. Морфологія кристалів мірабіліту, отриманих після розчинення кірок тенардиту

тичний та біпірамідальний. Обрис: Кончек - голчастий, стовпчастий, таблитчастий, ізометричний та скіпетроподібний (рис. 3); Бурулькая - ізометричний, стовбчастий, таблитчастий (рис.4). Розмір кристалів по довгій осі: Кончек - 0,1 до 2 мм; Бурулькая - 0,1-0,7 мм. Лінії на рентгенограмах: Кончек 7.622(100), 4.283(100), 3.799(15), 3.065(70), 2.873(40), 2.789(9), 2.685(33), 2.219(14), 2.086(20); Бурулькая - 7.648(7), 4.223(100), 3.802(15), 3.07(4), 2.886(24), 2.751(19), 2.682(26), 2.482(4), 2.229(5), 2.104(11). Серед закономірних зростків поширені паралельні та двійники.

Всі кристали гіпсу безколірні, водянопрозорі, зі скляним блиском. Показник заломлення коливається в межах 1,526-1,528. Більші значення відповідають кристалам голчастого обрису (Кончек). В 10\%-ній соляній кислоті грані кристалів піддаються частковому розчиненню.

Тенардит - $\mathrm{NaSO}_{4}$. Встановлений на Бурулькайському грязьовому вулкані у вигляді суцільних, щільних, з гладкою поверхнею, кірок білого кольору (рис.5,a). Характерні лінії на рентгенограмі 4.677(65), 3.85(14), 3.188(46), 3.085(38), 2.789(100), 2.651(57), 2.333(27), 1.867(34), 1.683(15), 1.665 (10), 1.555(13). Після розчинення цих кірок в дистильованій воді були отримані друзові та жеодоподібні форми тенардиту (рис.5,б, в). В окремих індивідах добре помітна його двовісність та позитивний характер. Показник заломлення тенардиту Ng' - 1,476, Np' - 1,470. Природні кірки, а також експериментально отримані форми тенардиту добре розчиняються в розбавленій $\mathrm{HCl}$ і дистильованій воді.

Мірабіліт - $\mathrm{NaSO}_{4} \times 10 \mathrm{H}_{2} \mathrm{O}$. Встановлений експериментально при кристалізації розчинених агрегатів тенардиту з Бурулькайського грязьового вулкану при температурі $18{ }^{\circ} \mathrm{C}$. Отримані кристали безколірні, прозорі, мають призматичний габітус (рис.6), двовісні, негативні, з показниками заломлення $\mathrm{Ng}-1,398, \mathrm{~Np}-1,394$. На повітрі швидко тьмяніють, а згодом переходять в білу непрозору пухку масу.

Астраханіт (Bloedite) - $\mathrm{Na}_{2} \mathrm{Mg}\left[\mathrm{SO}_{4}\right] \times 4 \mathrm{H}_{2} \mathrm{O}$. Встановлений разом з гіпсом та іншими водними сульфатами магнію на Кончекському та Бурулькайському грязьових вулканах. Мінерал поширений в кристалах та агрегатах. Габітус кристалів: ромбоедроподібний, призматично-дипірамідальний. Обрис їх сплощений, ізометричний. Розмір індивідів по осі $L_{2}$ змінюється від 0,2-0,7 мм (у сплощених ромбоедроподібних) до 1-1,4мм (у ізометричних призматично-дипірамідальних) (рис.7).

Сплощені кристали безбарвні, водянопрозорі, зі скляним блиском, ізометричні - каламутно-білі, з тьмяним блиском. Останні часто мають сліди розчинення. Для призматично-дипірамідальних кристалів характерні закономірні зростки.

Досліджені кристали астраханіту оптично негативні, двовісні. $\mathrm{n}_{\mathrm{g}}=1,490 ; \mathrm{n}_{\mathrm{m}}=1,488 ; \mathrm{n}_{\mathrm{p}}=1,486 ; \mathrm{n}_{\mathrm{g}}$ $\mathrm{n}_{\mathrm{p}}=0,004$. На рентгенограмах астраханіту відповідають лінії 4.562(26), 4.41(7), 3.99(4), 3.802(15), 3.351(19), 3.292(22), 3.255(21), 2.978(22), 2.682(26), 2.662(28), 2.589(9), 2.317(4), 2.3(5), 2.278(6). Bci індивіди та зростки кристалів астраханіту добре розчиняються в $\mathrm{HCl}$ і дистильованій воді.

Агрегати з астраханітом представлені жовновоподібними стяжіннями білого, буровато-жовтого кольору розміром від декількох міліметрів до 1см та пухкою суцільною масою. Форма стяжінь: ізометрична, сплющено-ізометрична (рис.8). Поверхня нерівна, з численними порожнинками і па-
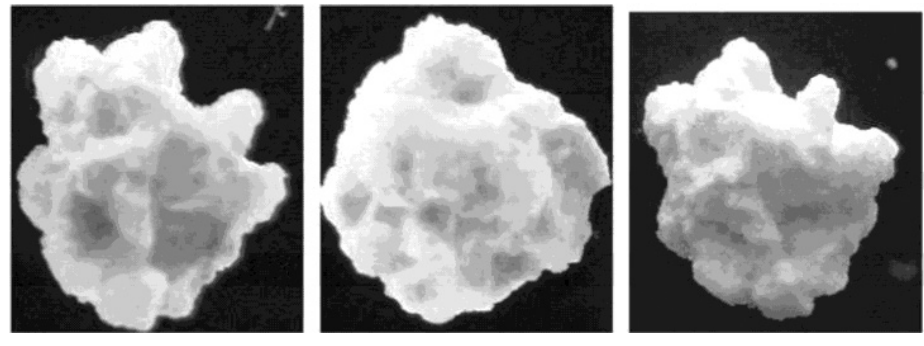

Рис.8. Морфологія полімінеральних астраханітвмісних агрегатів (Кончек) 

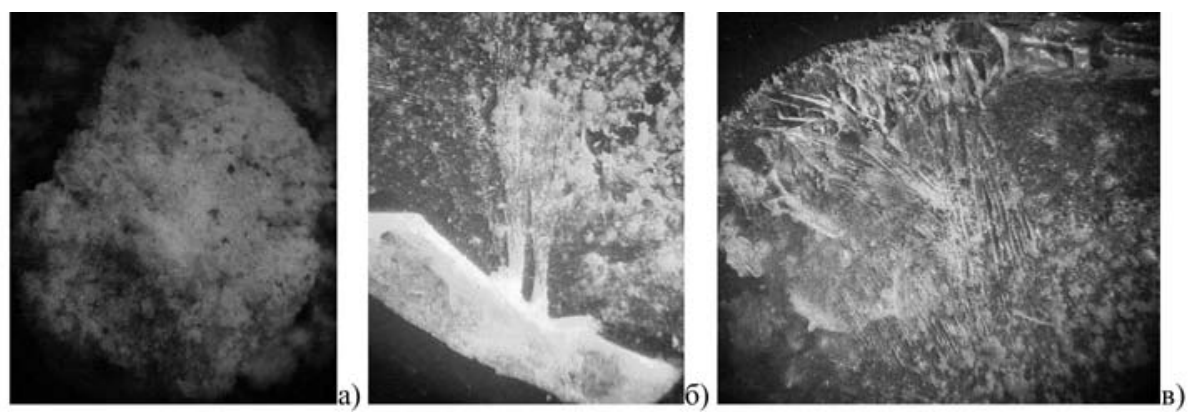

Рис.9. Морфологія виділень епсоміту. а - землисті агрегати; б, в - індивідуальні кристали

горбками. Під мікроскопом в стяжіннях спостерігається радіально-промениста будова, окремі індивіди орієнтовані віссю $\mathrm{L}_{2}$ перпендикулярно до нормалі до зовнішньої сфери. В окремих агрегатах спостерігається ледь помітна горизонтальна зональність.

Епсоміт - $\mathrm{MgSO}_{4} \times 7 \mathrm{H}_{2} \mathrm{O}$. Встановлений на Бурулькайському та Кончекському грязьових вулканах. На рентгенограмі йому відповідають лінії 5.997(17), 5.368(22), 4.498(16), 4.223(100), 3.802(15), $3.463(12), 3.432(10), 2.978(22), 2.886(24), 2.751(19), 2.682(26), 2.662(28), 2.385(7), 2.259(7)$, 2.208(12), 2.139(7), 2.104(11).

Природна форма виділення епсоміту - землисті агрегати білого кольору. Його кристали отримані лише після розчинення цих агрегатів в дистильованій воді. Вони прозорі, крихкі, мають віялоподібний, голчастий, списовидний обрис (рис.9). Показники заломлення цих кристалів в імерсіях $\mathrm{Ng}^{\prime}-1,462, \mathrm{~Np}^{\prime}-1,434$.

Гексагідрит - $\mathrm{MgSO}_{4} \times 6 \mathrm{H}_{2} \mathrm{O}$. Встановлений в агрегатах разом з астраханітом на Кончекському грязьовому вулкані та в асоціації з гіпсом, астраханітом та епсомітом на Бурулькайському грязьовому вулкані. Характерні лінії на рентгенограмах 5.467(10), 5.121(9), 4.562(100), 4.41(24), 4.133(11), 3.616(6), 3.466(5), 3.396(5), 3.202(5), 3.037(5), 2.974(31), 2.906(10), 2.688(15), 2.587(21). Візуально в агрегатах цей мінерал через тонкозернисту будову виділити неможливо. Проте після розчинення агрегатів в дистильованій воді і спостереженні за кристалізацією розчину його можна розпізнати за морфологією і показниками заломлення. Він утворює гілкоподібні і дендритові форми білого кольору. Показники заломлення цих новоутворень: $\mathrm{n}_{\mathrm{g}}=1,455 ; \mathrm{n}_{\mathrm{m}}=1,452 ; \mathrm{n}_{\mathrm{p}}=1,425$; $\mathrm{n}_{\mathrm{g}}-\mathrm{n}_{\mathrm{p}}=0,030$ (рис. 10 ).

Пентагідрит - $\mathrm{MgSO}_{4} \times 5 \mathrm{H}_{2} \mathrm{O}$. Зафіксовано тільки на рентгенограмах агрегатів разом з астраханітом і гексагідритом на Кончекському грязьовому вулкані. Характерні лінії пентагідриту на рентгенограмі 5.809(4), 5.121(9), 4.897(8), 4.429(28), 4.048(12), 3.987(9), 3.616(6), 3.466(5), 3.396(5), 3.292(93), 3.202(5), 3.037(5), 2.974(31), 2.825(27), 2.774(7), 2.688(15), 2.651(28). Виділити монофракцію пентагідриту з природної суміші нам не вдалось, оскільки цей мінерал знаходиться в дисперсній суміші з гексагідритом і, можливо, мірабілітом - $\mathrm{Na}_{2} \mathrm{SO}_{4} \times 10 \mathrm{H}_{2} \mathrm{O}$. Останні утворюють дрібні (до 3 мм) крихкі кулькоподібні форми білого кольору з радіально-променистою внутрішньою будовою (див. рис.10).
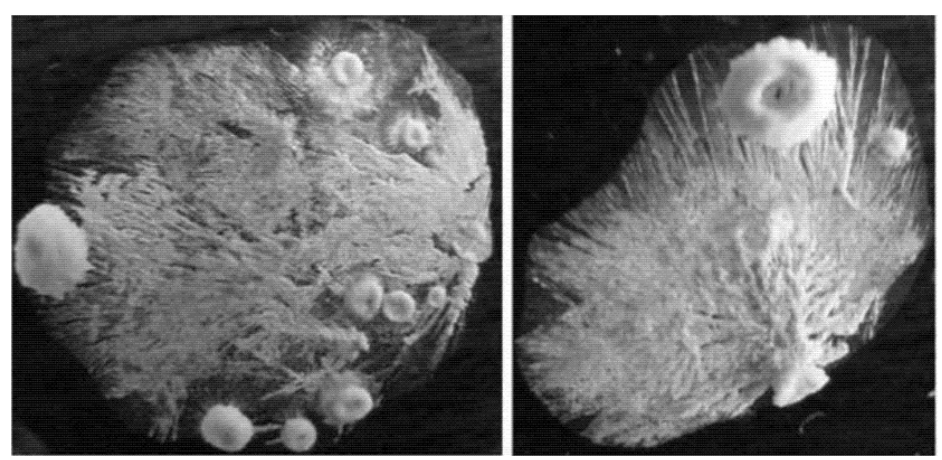

Рис.10. Морфологія новоутворених агрегатів після розчинення природної мінеральної суміші астраханіту, гексагідриту і пентагідриту при 20 ॰C

Сандерит - MgSO4?2H2O. Встановлений у складі полімінеральних новоутворень сопки Трубецького (Тарханський вулкан) разом 3 галітом, троною і тинкалконітом. Його лінії на рентгенограмі $7.087(7), 5.590(8), 4.392(24), 4.267(11)$, $3.887(5), 3.740(40), 3.450(16), 3.264(13)$, 3.081(38), 2.824(100), 2.970(10), 2.712(10), 2.650(52), 2.490(12). Для території України - це перша знахідка цього мінералу. В літературі сандерит описаний на соляних родовищах Німеччини. Його морфологічні і оптичні властивості у зв'язку з дисперс- 
ністю виділення встановити не вдалось. Також не вдалось отримати кристали сандериту синтетичним шляхом з розчинених у дистильованій воді природних агрегатів. Він разом з троною випадає в білий осадок.

Нітрати. Нітратин (Натрова селітра) $\mathrm{NaNO}_{3}$. Встановлений лише на сопці Ольденбургського (Булганак) у складі природних полімінеральних утворень разом 3 галітом, бурою, тинкалконітом, троною, де він знаходиться в дисперсному стані. Але після проведення експерименту з розчинення і кристалізації цих агрегатів ми отримали добре індивідуалізовані кристали нітротину, які утворилися відразу після утворення бури і галіту. Це безбарвні, водянопрозорі, чітко ограновані індивіди у вигляді плоских правильних шестигранників розміром до 0,1 мм (рис.11). Кристали дають чітку коноскопічну фігуру, характерну для одновісного негативного мінералу. Показники заломлення становлять $\mathrm{Ne}$ - 1,461, No' - 1,470. Деякі з новоутворених крис-

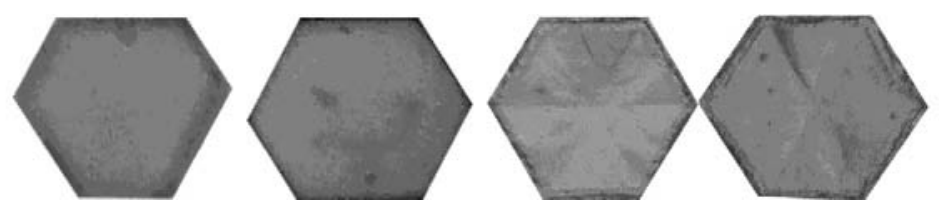

Рис.11. Кристали нітротину (?)

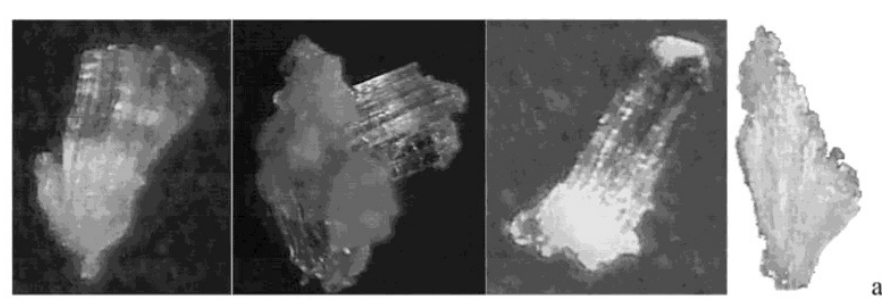

a)

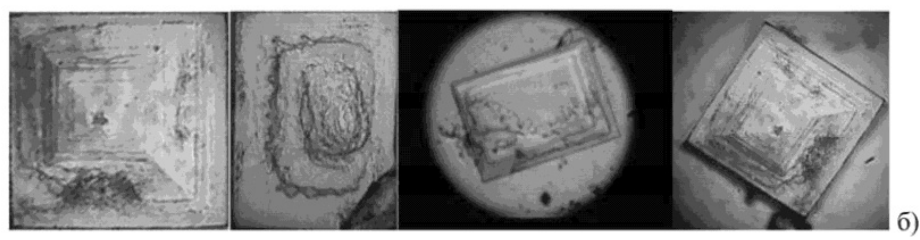

Рис.12. Галіт: а - волокнисті агрегати в природному стані; б - кристали галіту, що отримані шляхом кристалізації природних полімінеральних утворень (Булганак) талів в схрещених ніколях проявляють повну ізотропність (можливо, за рахунок ідеального збігу осі L3 з оптичною віссю).

Галіт - NaCl. Встановлений на всіх діючих сопках Булганакського, Тарханського та в одному з водних джерел Бурулькайського грязьових вулканів у складі полімінеральних новоутворень. Утворює поодинокі безбарвні, водянопрозорі волокнисті агрегати (рис.12,a), видовжені голчасті кристали розміром 0,2-0,8 мм та тонкодисперсну суміш.

Характерні лінії галіту на рентгенограмах 3.264(13), 2.824(100), 1.996(49), 1.629(15), 1.411(8). Показник заломлення волокнистих агрегатів мінералу з усіх точок спостереження приблизно однаковий і відповідає теоретичному значенню $(\mathrm{N}-1,544)$. Після розчинення полімінеральних утворень у дистильованій воді при $t^{\circ} \mathrm{C}=20$ з загальної маси через декілька хвилин починають кристалізуватися кристали галіту таблитчастого обрису (рис.12,б). Це безбарвні, прозорі, добре ограновані кристали кубічного габітусу. Більшість кристалів виявляє чітку зональну будову. Зони паралельні граням гексаедра. Розмір новоутворених індивідів при одноразовій кристалізації становить 0,2-0,3 мм.

\section{ОБГОВОРЕННЯ РЕЗУЛЬТАТІВ ТА ВИСНОВКИ}

Сопкові води грязьових вулканів Керченського півострова в цілому характеризуються як слабо мінералізовані. Загальна мінералізація їх коливається в межах від декількох г/л до 23-25 г/л.

Спостереження за хімізмом сопкових вод грязьових вулканів Керченського півострова не мають режимного характеру. Але одиничні заміри вказують на те, що вони мають непостійний склад. Навіть у межах одного вулкану, але на різних сопках коливання вмісту основних катіонів і аніонів відрізняються, і навіть суттєво. Все це вказує на багатофакторність і складність умов формування гідрохімічного балансу грязьових вулканів. Водневий показник (pH) сопкових вод змінюється від 6,5 до 9,4 [3]. Домінуючим катіоном для всіх вод $є \mathrm{Na}$. Найбільший (сопка Центральне Озеро-29,62 г/дм³) і найменший (сопка Павлова-4,83 г/дм³) його вміст зафіксований у межах одного грязьового вулкану - Булганакського. Вміст $\mathrm{Mg}^{2+}$ становить 0,06-0,6 г/дм³ $\mathrm{Ca}_{2}+-0,02-0,09$ г/дм3. Серед аніонів в більшості вод переважає Cl-. Його вміст коливається від 3-5 до 30 г/дм³. Вміст $\mathrm{SO}_{4}^{2}$ - змінюється від 0,9 до 2,8 г/дм³, a $\mathrm{CO}_{3}{ }^{2-}-4,0-7,2$ г/дм³. Майже всі води збагачені В - 0,40-3,7 г/дм³. Замірами 2007-2008 рр. в сопкових водах встановлено значний вміст нітратів, особливо на Булганакському грязьовому вулкані $(0,56-$ 4,7 г/дм³). Сопкові води також збагачені метаном, вуглекислим газом, азотом і гелієм. 
Виходячи із загальної концепції екзогенного мінералоутворення та особливостей грязевулканічного процесу, ми припускаємо таку схему сучасного мінералоутворення з сопкових вод грязьових вулканів Керченського півострова.

Мінерали утворились безпосередньо з водних розчинів після їх виливу з сопок і розтіканні на поверхні землі в умовах жаркого аридного клімату. До цього всі складові майбутніх мінералів в сопкових водах знаходились в іонному стані. Залежно від гідрохімічного складу вод конкретних сопок, розчинності солей і середовища ї розвантаження, мінералоутворення могло відбуватись за різними схемами.

Бура, галіт і трона утворились із сопкових вод гідрокарбонатно-хлоридно-натрієвого складу, збагачених бором і вуглекислотою. При цьому бура кристалізується першою, ще з водної фази, потім трона. Галіт виділяється останнім, після суттєвого випаровування сопкових вод і збагачення них хлористим натрієм. Оскільки цей процес відбувається у відкритій системі, нерівномірно, кристалізація хлористого натрію проходить спонтанно і галіт утворює лише агрегати або просто випадає в осадок. Кристали бури в умовах теплого і сухого повітря швидко втрачають воду і поступово переходять в тинкалконіт.

Водні сульфати утворились з сопкових вод сульфатно-хлоридно-натрієвого складу за такою схемою. Першим виділився гіпс, коли розчин при випаровуванні ще недостатньо був насичений хлористим натрієм. Після утворення гіпсу, ще з водної фази, сформувались кристали астраханіту, а потім на останніх стадіях випаровування - агрегати епсоміту і астраханіту. Епсоміт влітку, в сухих умовах, повільно втрачає воду і переходить в гексагідрит, а останній, в міру збільшення температури, - в пентагідрит. Восени, при зменшенні температури, в дощову погоду, всі новоутворені мінерали, крім гіпсу, переходять в розчин. При висиханні розчину з нього утворюється нова асоціація мінералів: епсоміт, гексагідрит, пентагідрит і, можливо, мірабіліт. Вони формують лише агрегатні суміші і зафіксувати їх присутність можна лише на рентгенограмах або при спостереженні кристалізації цих сумішей в лабораторних умовах.

Присутність двогідратного сульфату магнію (сандериту) серед новоутворень сопки Трубецької (Тарханського вулкану) є дещо несподіваною, оскільки, за літературними даними [4], вода в ній має хлоридно-гідрокарбонатно-натрієвий склад. Цей мінерал міг утворитися з сульфатно-хлориднонатрієвих вод, збагачених магнієм. Подібний склад мають води сопки Шилова, яка розташована в декількох десятках метрів від сопки Трубецькой. Раніше з водних сульфатів магнію у межах Чокраксько-Булганакської антикліналі був встановлений лише астраханіт (Тарханський грязьовий вулкан) [2].

Натрова селітра (нітротин) в природному стані $є$ рідкість, тому що розчинність цієї солі дуже велика, а концентрація нітратів у водах рідко досягає насиченого стану. Основні родовища натрової селітри знаходяться в пустелях Чилі, але генезис їх і нині залишається дискусійним. Ймовірно в її осадженні і кристалізації, крім нітрату натрію, важливу роль відіграють інші іони комплексних розчинів. Це можуть бути сульфати, борати, хлориди тощо.

1. Шнюков Е. Ф., Гнатенко Г. И., Нестеровский В. А. и др. Грязевой вулканизм Керченско-Таманского региона. - Киев: Наук. думка, 1992. - 200с.

2. Шнюков Е.Ф., Кутній В.А., Науменко С.П., Маслаков Н.А. Травертины и другие минеральные образования газоводных источников Керченского полуострова. // Геология и полезные ископаемые мирового океана. - 2007. - №3. - С. 5-14.
3. Шнюков Е.Ф., Науменко П. И., Лебедев Ю. С. и др. Грязевой вулканизм и рудообразование. - К.: Наук. думка, 1971. - 332 с.

4. Шнюков Е. Ф., Шереметьев В. М., Маслаков Н. А. и др. Грязевые вулканы Керченско-Таманского региона. - Краснодар: ГлавМедиа, 2006. - 176с.

\footnotetext{
${ }_{1}^{1}$ National Taras Shevchenko University of Kyiv, Kyiv, Ukraine

${ }^{1}$ Київський національний університет ім. Тараса Шевченка, м. Київ, Україна

2 Department of Marine Geology and Sedimentary Ore Formation of the NAS Ukraine, Kyiv, Ukraine

2 Відділення літології і морської геології НАН України, м. Київ, Україна
} 